\title{
THE EFFECT OF ADDITIONAL CORE STABILITY TRAINING IN INCREASING BODY FITNESS IN FOURTH FIELD ARTILLERY BATTALION SOLDIERS, CIMAHI, WEST JAVA, INDONESIA
}

\author{
Wita Hana Puspita'), Tjetjep Sudrajat²) \\ 1)Universitas Esa Unggul, Jakarta \\ 2)Field Health Detachment, Bandung
}

\begin{abstract}
Background: In recent years, fitness practitioners have increasingly recommended core stability exercises in body fitness conditioning programs. Greater core stability may benefit body fitness performance by providing a foundation for greater force production in the upper and lower extremities. The study objective was to investigate the effect of additional core stability training in increasing body fitness among soldiers.

Subjects and Method: A quasy experiment was conducted at fourth field artillery battalion soldiers, Cimahi, West Java, Indonesia. A sample of 20 soldiers was selected for this study and divided into two groups, (1) 10 soldiers received core stabilty exercise (intervention group), and (2) 10 soldiers received common exercise (control group). The dependent variable was physical fitness. The independent variable was core stability. Exercise was conducted three times a week for 4 weeks. Physical fitness was measured by physical fitness assessment form. Mean difference of physical fitness after intervention between groups was examined using independent $t$-test.
\end{abstract}

Results: After intervention, mean score of physical fitness in the intervention group (Mean=3.90; $\mathrm{SD}=1.52)$ was higher than control group (Mean=1.60; $\mathrm{SD}=0.70)$ and it was statistically significant ( $\mathrm{p}<0.001)$.

Conclusion: Core stability exercise can be used to improve physical fitness in fourth field artillery battalion soldiers.

Keywords: core stability exercise, physical fitness

Correspondence:

Wita Hana Puspita. Universitas Esa Unggul, South Jakarta, Indonesia. Email: wita.tj0408@gmail.com. 